\title{
Hydrothermal redox synthesis of cobalt and manganese spinels using metal nitrates
}

\author{
C Aygul A. Mammadova, ${ }^{1 *}$ Sevinj N. Osmanova, ${ }^{1+}$ Sabira A. Agayeva, ${ }^{1}$ \\ Aydar A. Mejidov, ${ }^{1}$ and Imamaddin R. Amiraslanov ${ }^{2}$ \\ ${ }^{1}$ Institute of Catalysis and Inorganic Chemistry Named after Acad. M.F. Naghiyev of Azerbaijan National \\ Academy of Sciences. H. Javid Ave, 113. Baku, AZ1143. Azerbaijan Republic. \\ ${ }^{2}$ Institute of Physics of Azerbaijan National Academy of Sciences. H. Javid Ave, 131. \\ Baku,AZ1143.Azerbaijan Republic.E-mail: o.sevinc1985@rambler.ru
}

\section{*Supervising author; ${ }^{+}$Corresponding author}

Keywords: hydrothermal synthesis, oxides, spinel structures, lithium ion batteries.

\begin{abstract}
The hydrothermal reduction of cobalt, manganese and lithium nitrates with ethylene glycol was studied in the temperature range $100-270{ }^{\circ} \mathrm{C}$ in order to obtain nanostructured spinels. The phase composition, particle sizes of the reaction products, and their morphology studied by using IR spectroscopy, X-ray diffractometry, and scanning electron microscopy.

We found that the nature of the reaction product of manganese and cobalt nitrates with ethylene glycol (EG) depends on the reaction temperature, the ratio of metal nitrate: ethylene glycol and reaction time. In excess of the reducing agent at temperatures up to $140{ }^{\circ} \mathrm{C}$, observed the formation of metal oxalates. The main product of hydrothermal reduction of manganese nitrate with ethylene glycol at temperatures of $150{ }^{\circ} \mathrm{C}$ and $180{ }^{\circ} \mathrm{C}$ is manganese oxide $\mathrm{Mn}_{3} \mathrm{O}_{4}$ (Hausmanite). At $200{ }^{\circ} \mathrm{C}$ obtained the mixture of manganese oxide $\left(\mathrm{Mn}_{3} \mathrm{O}_{4}\right)$ and carbonate $\left(\mathrm{MnCO}_{3}\right)$. In accordance with the data of $\mathrm{X}$-ray phase analysis at $220{ }^{\circ} \mathrm{C}$ and $240{ }^{\circ} \mathrm{C}$, the only reaction product in both cases is manganese carbonate.

It was obtained two types of structures on electron-microscopic images of the non-calcined sample at $200{ }^{\circ} \mathrm{C}$ : needle-shaped and spherical clusters. It can be assumed that these structures belong to the phases $\mathrm{Mn}_{3} \mathrm{O}_{4}$ (Hausmanite) and manganese carbonate $\mathrm{MnCO}_{3}$, respectively.

When reduced cobalt nitrate with ethylene glycol in the temperature range $120-220{ }^{\circ} \mathrm{C}$, gives a main amorphous phase, and on X-ray diffraction patterns are observed weak reflections corresponding to cobalt oxide $\mathrm{Co}_{3} \mathrm{O}_{4}$.

It was shown that upon calcination (at $750{ }^{\circ} \mathrm{C}$ ) of the samples during the reduction of the mixture of cobalt and manganese nitrates, was obtained the spinel phase of the composition $(\mathrm{Co}, \mathrm{Mn})(\mathrm{Co}, \mathrm{Mn})_{2} \mathrm{O}_{4}$.

In a similar way were obtained $\mathrm{Li}_{2} \mathrm{CoMn}_{3} \mathrm{O}_{8}$ and $\mathrm{LiCoO}_{2}$ phases (with average particle sizes of $42 \mathrm{~nm}$ and $30 \mathrm{~nm}$ ), which can be used as cathodes in lithium batteries.
\end{abstract}

\section{References}

[1] Qilong Liao, Rina Tannenbaum, Zhong Lin Wang. J. Phys. Chem. B. 2006. Vol.110. Iss.29. P.1426214265. DOI: 10.1021/jp0625154

[2] M. Stefanescu, M. Stoia, C. Caizer, et al. J. Therm Anal Calorim. 2009. Vol.97. P.245-250.

DOI: 10.1007/s10973-009-0250-x

[3] Sridhar Komarnenia, Young Dong Noha, Joo Young Kima, Seok Han Kima, Hiroaki Katsukib. Z. Naturforsch. 2010. Vol.65b. P.1033-1037.

[4] I.G. Mekhdiev, A.A. Medzhidov, Z.D. Ibaev, P.A. Fatullaeva, B. Yalçin. J.Inorg.Chem. 2013. Vol.58. No.8. P.915-918

[5] Zishan Husain Khan. Recent Trends in Nanomaterials: Synthesis and Properties. Springer Singapore. 2017. P.217. DOI:10.1007/978-981-10-3842-6

[6] Linda J. Cote, Amyn S. Teja, Angus P. Wilkinson, Z. John Zhang. J. Mater. Res. 2002. Vol.17. Iss.9. P.2410-2416. DOI:10.1557/JMR.2002.0352

[7] Linda A. Bruce, John V. Sanders, Terence W. Turney. J. Clays and Clay Minerals. 1986. Vol.34. Iss.1. P.25-36. DOI: 10.1346/CCMN.1986.0340104

[8] C.Y. Haw, F. Mohamed, C.H. Chia, S. Radiman, H. Lim. J. Ceramics International. 2010. Vol.36. Iss.4. P.1417-1422. DOI:10.1016/j.ceramint.2010.02.005 
HYDROTHERMAL REDOX SYNTHESIS OF COBALT AND MANGANESE SPINELS USING METAL NITRATES_116-123

[9] A.N. Bugrov, O.V. Almjasheva. J. Nanosystems: physics, chemistry, mathematics. 2013. Vol.4. Iss.6. P.810-815.

[10] R.B. Yahya, H. Hayashi, T. Nagase, T. Ebina, Y. Onodera, N. Saitoh. J. Chem. Mater. 2001. Vol.13. P.842-847. DOI: $10.1021 / \mathrm{cm} 000561 \mathrm{p}$

[11] H. Hayashi, K. Torii. J. Mater. Chem. 2002. Vol.12. P.3671-3676. DOI: 10.1039/B207052A

[12] J. Lee, A.S. Teja. J. Supercrit. Fluid. 2005. Vol.35. Iss.1. P.83-90. DOI: 10.1016/j.supflu.2004.12.005

[13] K. Matsui, T. Noguchi, N.M. Islam et al. J. Cryst. Growth. 2008. No.61. P.850-854. DOI:10.1016/j.matlet.2006.06.006

[14] K. Sue, M. Suzuki, K. Arai et al. J. Green Chem. 2006. Vol.8. P.634-638. DOI:10.1039/B518291C

[15] Naoki Nitta, Feixiang Wu, Jung Tae Lee, Gleb Yushin. J. Materials Today. 2015. Vol.18. Iss.5. P.252264. DOI: $10.1016 /$ j.mattod.2014.10.040

[16] Qifeng Zhang, Evan Uchaker, Stephanie L. Candelaria, Guozhong Cao. J. Chem. Soc. Rev. 2013. Vol.42. P.3127-3171. DOI:10.1039/C3CS00009E 